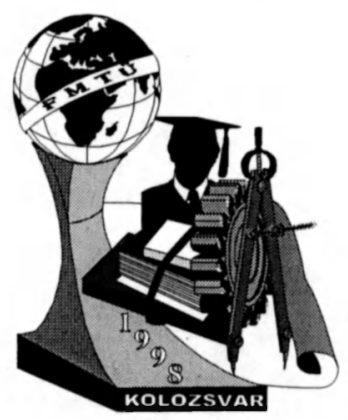

\title{
Rideg anyagok ultraprecíziós köszörülése
}

\author{
Dr. Mészáros Imre, Tóth Lajos
}

\begin{abstract}
Nowadays the utilisation of ceramics and glasses as structural materials became more and more widespread. The growing interest can be credited to the development of advanced materials possessing higher strength at elevated temperatures, and greater fracture toughness. These reasons necessitate the examination of the manufacturing techniques of the advanced materials. Ultraprecision grinding is one of the most productive manufacturing technologies. In recent years the ductile mode grinding of brittle materials has been developed. While conventional grinding makes shape on a surface by crushing or brittle fracture, during ultraprecision grinding chips are removed by ductile material removal mechanisms, which reduces polishing time remarkably.

In our department we started to build an ultraprecision grinding machine which has raised several questions.
\end{abstract}

\section{Bevezetés}

Üveg és mérnöki kerámiából készült alkatrészeket egyre gyakrabban alkalmaznak a korszerü berendezésekben. Ezek megmunkálására kiforrott technológiákat használnak. Szintén egyre nagyobb az érdeklödés az aszférikus mikron alatti pontosságú felületek iránt. Optikai üvegböl készült lencsék használatával a hagyományos optikai rendszerek jelentősen leegyszerüsithetők, a beépített lencsék száma a felére csökken.

$\mathrm{Az}$ aszférikus felületek sok elönnyel rendelkeznek a szferikus felületekkel szemben, de a szferikus felületekhez használt megmunkálási eljárásokkal nehéz pontosan és hatékonyan megmunkálni öket. Ezen okok miatt különböző új megmunkálási módszereket fejlesztettek ki aszférikus felületek elöállítására, amelyek a gyakorlatban is megjelentek [1].

Az ultrapreciziós kerámia alkatrészek szintén egyre nagyobb érdeklődésre tartanak számot. Mivel a kerámiák rengetegféle összetétele létezik, ennek következtében felhasználásuk is sokrétü. Kerámiákat alkalmaznak a gyógyászatban (pl. protézisek készitése), autóiparban (csapágyak, tömítés nélkül müködő szelepek stb.), és sok egyéb területen [2].

A Budapesti Müszaki Egyetem Gépgyártástechnológia Tanszékén rideg anyagok köszörülésére alkalmas szerszámgép építésébe kezdtünk, az ennek során felmerült problémákat foglalja össze a cikk. 


\section{Rideg anyagok forgácsolás elmélete}

Rideg anyagok forgácsleválasztása általában eltér a szivós anyagokétól. Az eltérés oka, hogy az él alatt a nagy fajlagos terhelés miatt repedések keletkeznek. A viszonyokat jól érzékelteti az 1 . ábra.

A repedéseknek két fajtáját különböztetjük meg; a kagylós- és a mélységi irányú repedést. A repedés nagysága a szemcse alakjától, a terhelés nagyságától, és az anyagminőségtől függ elsősorban, de jelentős szerepe van a szemcse belépésétől a kilépésig eltelt időnek is. Ennek az időnek a csökkentésével a repedések nagysága csökkenthető, ezáltal javul a szerszám leképező képessége, és csökken a repedezett réteg vastagsága. (Rideg anyagok szabályos éllel történő ultraprecíziós forgácsolásakor ezért a szerszámot ultrahang frekvenciával rezgetik.)

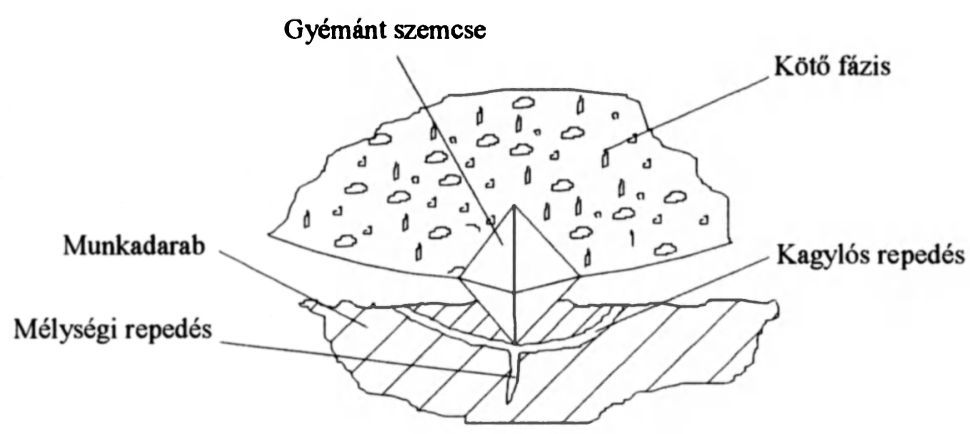

1. ábra

Forgácsolás éles szerszám esetén

Kopott szemcse esetén a megnövekedett terhelőerő nagyobb felületre fejti ki ugyanazt a fajlagos erőt, mint éles szemcse esetén, ezért a repedések száma és mérete megnövekszik (2. ábra).

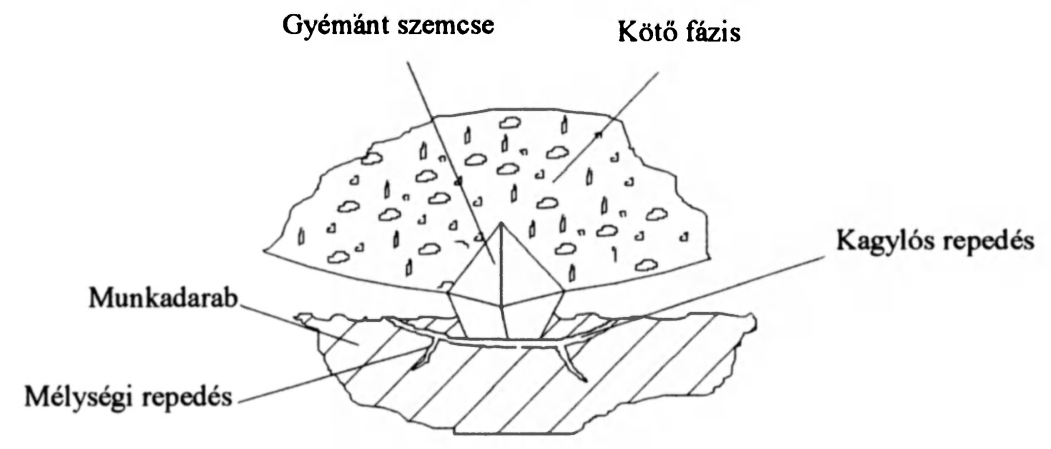

2. ábra

Forgácsolás kopott szerszám esetén

A mélységi repedések a köszörülés után megmaradnak a felületi rétegben, rontva ezzel az optikai elem transzmisszív képességét. Az utóbbi idők kutatómunkája az optikai üvegek ultraprecíziós köszörülése terén arra irányult, hogy a mélységi repedések csökkenjenek, illetve megszünjenek. A mélységi repedések duktilis forgácsolási viszonyok kialakitásával megszüntethetők (3. ábra).

A duktilis forgácsolási viszonyok kialakulását a korongszemcsék speciális leszabályozásával érik el. A duktilis forgácsolási technológia ma még teljesen újnak számít. Duktilis forgácsolási viszonyok elérése 
érdekében az anyagminőségtől függő nyomófeszültséget kell az üregben elérni ahhoz, hogy az anyag megfolyjon, és ne repedjen.

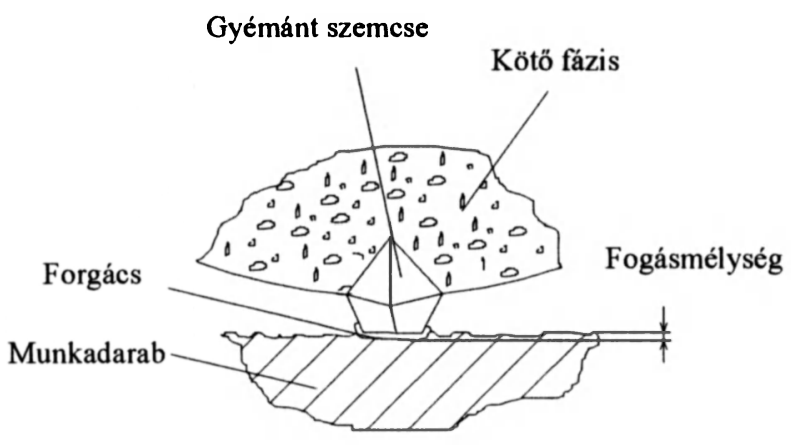

3. ábra

Duktilis forgácsolás

A rideg anyagok köszörüléséhez jellemzöen gyémánt köszörükorong használatos. A duktilis forgácsolási viszonyok kialakulását a korong speciális leszabályozásával, és a forgácsolási paraméterek helyes megválasztásával érik el. A pontos leszabályozással a köszörükorong axiális és radiális ütése lecsökken. A leszabályozás (profilozás, élesítés, éles szemcsék koptatása) végrehajtható egy SiC és korund szabályozó kőnek a munkadarab helyére történő befogásával. Ultraprecíziós köszörülés közben a korong legnagyobb axiális és radiális ütése nem haladhatja meg az $1 \mu \mathrm{m}$-t, a profilpontosság pedig a $0,1 \mu \mathrm{m}$-t. A szemcse csúcsa és a kötés közti távolságot többnyire a szemcseátmérő függvényében adják meg, úgymint $(1 / 3 \div 1 / 6)^{*}$ szemcseátmérő. Egy D3 (FEPA szabvány) szemcsét tekintve annak átmérője $2 \div 5 \mu \mathrm{m}$, a kötésből kiálló szemcsenagyság $1 \div 2,5 \mu \mathrm{m}$. Kötőanyagként általában mügyanta, bronz vagy galvanikus kötést alkalmaznak [3].

\section{Aszférikus felületek köszörülése}

A korszerü optikai berendezésekben a hagyományos, több szferikus felület összekapcsolása útján előálló aszférikus lencséket vagy tükröket felváltják az egy darabból kimunkált forgásszimmetrikus aszférikus lencsék vagy tükrök. Az aszférikus felületek sok előnnyel rendelkeznek a szferikus felületekkel szemben (egyszerübb lencsefoglalat, kisebb fényveszteség, kisebb tömeg, és kisebb helyigény stb.), de a szferikus felületekhez használt megmunkálási eljárásokkal nehéz pontosan és hatékonyan megmunkálni öket. Az ultraprecíziós köszörüléstől a megmunkálás idejének jelentős csökkenése, a leppelő polírozó fázisok elmaradása várható.

Hatékony anyagleválasztás és a kívánt felületi minőség elérése érdekében a munkadarab és a köszörü szerszám érintkezési felületének a lehető legnagyobbnak kell lennie. Mivel csak a szférikus és toroid felületek teszik lehetővé a teljes felületen történő érintkezést, ezért a részleges vagy vonal menti érintkezés tünik a legjobb alternatívának. 


\section{Ultraprecíziós gépépítés}

A Budapesti Müszaki Egyetem Gépgyártástechnológia Tanszékén rendelkezésre áll egy ultraprecíziós esztergagép, mely a Csepeli Szerszámgépgyárban készült. Ezt a szerszámgépet tesszük alkalmassá ultraprecíziós köszörülési feladatok elvégzésére, amellett hogy az eredeti feladatát, az esztergálást is el tudja látni. Ennek érdekében a gépet nagyfordulatú pótorsóval kívánjuk felszerelni.

A gép HEMBRUG licensz alapján készült, a vezérlése NUM $760 \mathrm{CNC}$, amely $0,1 \mu \mathrm{m}$ legkisebb programozható szánelmozdulást tesz lehetővé. A szerszámgép hidrosztatikus csapágyakkal rendelkezik.

A gépátalakítás célja az ultraprecíziós eszterga alkalmazási lehetőségeinek kibővítése.

A nagyfordulatú pótorsó a késtartó szánra kívánjuk felszerelni az esztergakéstartó helyére. A munkadarab az eszterga föorsójába lesz befogva. A köszörülö fömozgás mellett a köszörükorong $\mathrm{X}$ és $\mathrm{Z}$ irányban is mozgatható. A köszörüorsó orientációja a tervek szerint változtatható lesz. Alaphelyzetben a pótorsó tengelye az YZ síkban helyezkedik el, merőlegesen a főorsó tengelyére, de a főorsóval párhuzamos helyzetben is fel lehet majd szerelni, lehetővé téve ezzel a homlokfelületre meröleges furatok köszörülését. A köszörüszerszám méretét a munkadarab korlátozza, ezért van szükség nagysebességü köszörüorsó alkalmazására.

A gép átalakításának megtervezése során számos szempontot figyelembe kellett venni. A legfontosabbak a következök:

- A pótorsót tartó felépítménynek nagy statikus és dinamikus merevséggel kell rendelkeznie a rezgések elkerülése érdekében.

- Figyelembe kell venni az ultraprecíziós eszterga által adott méretkorlátokat.

- A felépítmény méretét a késtartó szán teherbírása korlátozza.

- Az orsótartó szerkezetnek biztosítania kell a mikron pontosságú beállítási lehetőséget

Figyelembe véve a fenti megfontolásokat a Federol Mogul/Westwind 90HF2X jelü köszörüorsóját választottuk $\mathrm{ki}$, és rendeltük meg. A föorsó légcsapágyazott, vízhütéssel rendelkezik, maximális fordulatszáma 30000 ford/perc. Vízszintesen és függőlegesen is felszerelhető.

\section{Összefoglalás}

Az ultraprecíziós eszterga átalakitása ultraprecíziós köszörüvé, az eredeti funkció megőrzése mellett, jelentősen kiterjesztette az alkalmazás határait. Optikai üvegek köszörülése mellett ultraprecíziós kerámia és keményfém alkatrészek szintén köszörülhetök a géppel. Mivel a gép az eredeti funkció elvégzésére is alkalmas, lehetséges az esztergálás, köszörülés és polírozás elvégzése egy felfogásban. Az általunk tervezett konstrukció új perspektívákat nyit, és új lehetőségeket biztosít az ultraprecíziós technológia területén.

\section{Felhasznált irodalom}

[1] T. Nishiguchi, Y. Koizumi, Y. Maeda, M. Mausuda, K. Nagayama: Improvement of Productivity in Aspherical Precision Machining with In-situ Metrology, Annals of the CIRP, 40/1/1991, 367-370

[2] R. J. Brook: Concise Encyclopedia of Advanced Ceramic Materials, Pergamon Press, 1991, 587. Old 